\title{
Differential gene expression of granulosa cells after ovarian superstimulation in beef cattle
}

\author{
F C F Dias, M I R Khan, M A Sirard ${ }^{1}$, G P Adams and J Singh \\ Department of Veterinary Biomedical Sciences, Western College of Veterinary Medicine, University of Saskatchewan, \\ 52 Campus Drive, Saskatoon, Saskatchewan, Canada S7N 5B4 and ${ }^{1}$ Departement des Sciences Animales, \\ Centre de Recherche en Biologie de la Reproduction, Université Laval, Sainte-Foy, Quebec, Canada G1K 7P4
}

Correspondence should be addressed to J Singh; Email: jaswant.singh@usask.ca

\begin{abstract}
Microarray analysis was used to compare the gene expression of granulosa cells from dominant follicles with that of those after superstimulatory treatment. Cows were allocated randomly to two groups (superstimulation and control, $n=6 / g r o u p)$. A new follicular wave was induced by ablation of follicles $\geq 5 \mathrm{~mm}$ in diameter, and a progesterone-releasing device controlled internal drug release (CIDR) was placed in the vagina. The superstimulation group was given eight doses of $25 \mathrm{mg} \mathrm{FSH}$ at 12-h intervals starting from the day of wave emergence (day 0), whereas the control group was not given FSH treatment. Both groups were given prostaglandin $F_{2 \alpha}$ twice, $12 \mathrm{~h}$ apart, on day 3 and the CIDR was removed at the second injection; 25 mg porcine luteinizing hormone (pLH) was given $24 \mathrm{~h}$ after CIDR removal, and cows were ovariectomized $24 \mathrm{~h}$ later. Granulosa cells were collected for RNA extraction, amplification, and microarray hybridization. A total of 190 genes were downregulated and $\mathbf{2 8 0}$ genes were upregulated. To validate the microarray results, five genes were selected for real-time PCR (NTS, FOS, THBS1, FN1, and IGF2). Expression of four genes increased significantly in the three different animals tested (NTS, FOS, THBS1, and FN1). The upregulated genes are related to matrix remodeling (i.e. tissue proliferation), disturbance of angiogenesis, apoptosis, and oxidative stress response. We conclude that superstimulation treatment $i$ ) results in granulosa cells that lag behind in maturation and differentiation (most of the upregulated genes are markers of the follicular growth stage), ii) activates genes involved with the NFE2L2 oxidative stress response and endoplasmic reticulum stress response, and iii) disturbs angiogenesis.

Reproduction (2013) 146 181-191
\end{abstract}

\section{Introduction}

The primary action of follicle-stimulating hormone (FSH) in the female is to promote follicular development (Adams et al. 1992). A group of follicles (wave or cohort) emerges after an increase in peripheral FSH concentrations (Adams et al. 1992, 2008, Jaiswal et al. 2004). Follicular products from the growing cohort, particularly the dominant follicle, are responsible for suppressing FSH concentrations (Adams 1994, Berfelt et al. 1994). When circulating $\mathrm{FSH}$ begins to decline, subordinate follicles stop growing and become atretic (Adams et al. 1993a, 1993b, Berfelt et al. 1994, Ginther et al. 1999). However, the dominant follicle acquires luteinizing hormone $(\mathrm{LH})$ receptors on its granulosa cells (Adams 1994) and is, therefore, no longer dependent on FSH (Bao \& Garverick 1998, Ginther et al. 1999). Maintenance of elevated circulating concentrations of $\mathrm{FSH}$ rescues the subordinate follicles within the cohort from regression and thereby delays or prevents selection of a single dominant follicle, i.e. results in multiple dominant follicles capable of ovulating (superstimulatory/ superovulatory response) (Scanlon et al. 1968, Wildt et al. 1975, Adams et al. 1993b, Mapletoft et al. 2002).

Superstimulation is a technique that has been used widely in animal breeding programs, both for commercial and research purposes. One of the major limitations of superovulation is the extreme variability in the response to treatments. In one study (Looney 1986), $30 \%$ of 2048 cows produced $70 \%$ of the total embryos collected, whereas $24 \%$ of cows failed to produce an embryo. Major determinants of the superstimulatory response are the number of follicles available at wave emergence (Singh et al. 2004) and the timing of the onset of treatments in relation to wave emergence (Nasser et al. 1993, Adams et al. 1994, Adams 1998). The reason for the high variation among individuals in the number of follicles recruited into a wave and the proportion of follicles that fail to ovulate after superovulatory treatment remains unknown. The effect of superstimulation treatment on the follicular environment and oocyte quality is also not well understood. Previous studies suggest that superstimulation can trigger genes related to the oxidative stress response of embryos of mice 
(Rossignol et al. 2006, Fauque et al. 2007, Sato et al. 2007) and cattle (Mundim et al. 2009). However, these studies involved analysis of the genetic status of embryos and tested only a few genes. Microarray technology allows a better understanding of molecular status by evaluating the expression levels of thousands of genes at the same time.

Current parameters used for determining oocyte competence are based on oocyte morphology and the ability to fertilize and to develop to the blastocyst stage. However, the molecular status of follicles and oocytes subsequent to superstimulation is not known. Therefore, there is a need to determine how gene expression of a follicle is affected by preventing follicular selection and whether alterations in intracellular molecular pathways can explain the extensive individual variability in the response to superstimulation treatment.

The objective was to determine the effect of superstimulation treatment on major molecular and cellular pathways, as evidenced by gene expression of granulosa cells. We tested the hypothesis that, given an equivalent growing phase, the molecular pathways related to cell differentiation are altered in granulosa cells from superstimulated follicles compared with those of single (unstimulated) pre-ovulatory follicles.

\section{Materials and methods}

\section{Animals and treatments}

The experiment was conducted on 12 cross-bred beef cows, weighing $515-795 \mathrm{~kg}$, maintained in outdoor pens at the University of Saskatchewan during October to December. Procedures were conducted in accordance with the guidelines of the Canadian Council on Animal Care and were approved by University of Saskatchewan Protocol Review Committee.

To synchronize estrus and ovulation, the cows were given two luteolytic doses of prostaglandin $\left(\mathrm{PGF}_{2 \alpha ;} 500 \mu \mathrm{g}\right.$ cloprostenol i.m.; Estrumate, Schering-Plough Animal Health, Pointe-Claire, PQ, Canada) 14 days apart. Emergence of a new follicular wave was synchronized by transvaginal ultrasoundguided ablation of follicles $\geq 5 \mathrm{~mm}$ in diameter $5-8$ days after ovulation. A new follicular wave was expected to emerge 1 day after ablation (Berfelt et al. 1994). An intravaginal, progesterone-releasing device (controlled internal drug releasebovine (CIDR-B) Pfizer Canada, Inc., Brandon, Manitoba Canada) was placed in the vagina immediately after follicle ablation. The cows were then allocated randomly to two groups: i) superstimulation group $(n=6)$ and ii) control group (no superstimulation, $n=6$; Fig. 1). Starting 1 day after follicle ablation, i.e. on the day of wave emergence (day 0), cows in the superstimulation group were administered eight doses of $\mathrm{FSH}$ i.m. (Folltropin-V; Bioniche Animal Health, Belleville, ON, Canada; each equivalent to $25 \mathrm{mg} \mathrm{NIH}-\mathrm{FSH}-\mathrm{P} 1)$ at $12-\mathrm{h}$ intervals over 4 days. The control group was not given any FSH treatment. On day 3, cows in both groups were given 2 i.m. doses of $25 \mathrm{mg} \mathrm{PGF}_{2 \alpha} 12 \mathrm{~h}$ apart, and the CIDR was removed at the time of the second $\mathrm{PGF}_{2 \alpha}$ treatment. Cows were given $25 \mathrm{mg}$ porcine $\mathrm{LH}(\mathrm{pLH})$ i.m. (Lutropin-V, Bioniche Animal Health) $24 \mathrm{~h}$ after CIDR removal and were ovariectomized $24 \mathrm{~h}$ after pLH treatment.

\section{Tissue collection}

Ovariectomies were performed using a colpotomy approach, as described by Singh et al. (1998). Briefly, caudal epidural anesthesia was induced with 5-10 ml lidocaine (Lidocaine $\mathrm{HCl}$ 2\%, Catalog \# 1LID009P, Bimeda-MTC Animal Health, Inc., Lavaltrie, QC, Canada). The perineum was disinfected using an iodine-based detergent solution. A small incision was made in the dorsolateral aspect of the vaginal fornix. The peritoneum was ruptured manually, allowing direct access to and palpation of the reproductive tract. Local anesthesia was manually applied to the ovarian pedicle using a gauze soaked with lidocaine. A plastic clip was applied to the ovarian pedicle to minimize hemorrhage. The chain of an ecraseur was looped

\section{Superstimulation group $(n=6)$}

Wave emergence

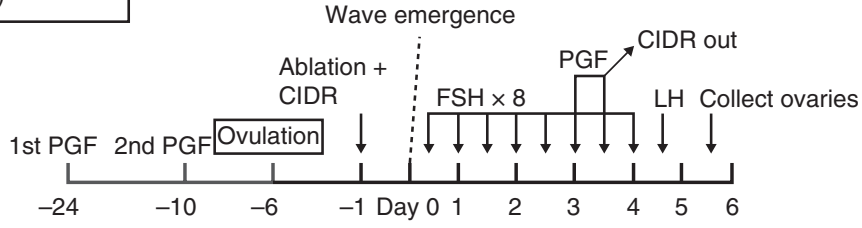

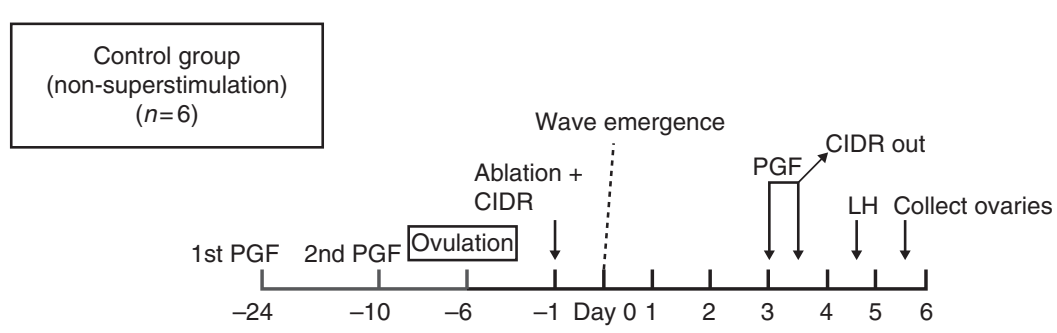

Figure 1 Experimental protocol used to test the effect of ovarian superstimulation on gene expression in granulosa cells. At 5 to 8 days after ovulation, follicles $\geq 5 \mathrm{~mm}$ were ablated and a progesterone-releasing device (CIDR) was placed intravaginally. FSH treatment was initiated at wave emergence (day 0). Cows in the superstimulation group were given eight doses of FSH at 12-h intervals, and cows in the control group were not treated with FSH. On day 3, cows in both groups were given $\mathrm{PGF}_{2 \alpha}$ and the CIDR was removed. LH was given $24 \mathrm{~h}$ after CIDR removal, and cows were ovariectomized $24 \mathrm{~h}$ later. 
around the ovarian pedicle and slowly tightened until the ovarian attachments were severed. The ovaries were placed in polyethylene bags, kept on ice, and transported to the laboratory within 5 min after collection. The number of follicles in both ovaries was counted and the dominant follicle (control group) or the three largest follicles (superstimulated group) were identified by visual assessment and confirmed by measuring the diameter after follicles were opened. The goal was to collect antral and mural granulosa cells. Antral granulosa cells were those floating freely in the follicular fluid, while the mural granulosa cells were those that were attached to the inner wall of the follicle. Antral granulosa cells were collected by aspiration of the follicular antrum using a 20-gauge needle and syringe. Follicles were flushed three times with Dulbecco's PBS (Invitrogen Corporation, Catalog \# 14190-144). The cumulus-oocyte complex was then identified and separated from the aspirate. The follicular fluid was centrifuged and the pellet of antral granulosa cells was harvested. The collapsed follicles were then cut in half using a scalpel blade and the inner follicular wall was scraped with a microbiology culture loop (LightLabs, Catalog \# PD104, Dallas, TX, USA) to remove the mural layer of granulosa cells. The mural and antral granulosa cells were pooled for each animal, snap frozen in liquid nitrogen and kept at $-80{ }^{\circ} \mathrm{C}$ for later microarray analysis.

\section{RNA extraction and amplification}

Total RNA was extracted using the Trizol extraction method according to the manufacturer's instructions (Invitrogen Life Technology) and resuspended in $50 \mu \mathrm{l}$ nuclease-free water. RNA was purified using the Arcturus PicoPure RNA Isolation and Purification Kit (Catalog \# KIT0204, Applied Biosystem) following the manufacturer's protocol. The purification process includes DNAse treatment to remove DNA and final pure RNA was recovered in $15 \mu \mathrm{l}$ elution buffer. RNA quality was evaluated using Bioanalyzer-2100 (Agilent Technologies, Palo Alto, CA, USA) with the RNA NanoLab Chip (Catalog \# 50671511, Agilent Technologies). Only RNA samples with RNA integrity number $>5$ were used for microarray hybridizations.

Samples (5 ng) of purified RNA were used for amplification. For the superstimulation group, equal amounts of RNA from the three largest follicles were pooled and a total of $5 \mathrm{ng}$ RNA from the pooled sample was used. For the control group, the same amount of RNA was obtained from the single dominant follicle. The amplification process was chosen with the intent of increasing the amount of genetic material used for microarrays. A linear amplification was performed using two 6-h rounds of T7 RNA polymerase (RiboAmp HS ${ }^{\text {Plus }}$ RNA Amplification Kit; Molecular Devices, Sunnyvale, CA, USA) following the manufacturer's directions. The antisense RNA (aRNA) output was measured using NanoDrop ND-1000 (NanoDrop Technologies, Wilmington, DE, USA).

\section{Sample labeling, hybridization, and microarray scanning}

For each sample, $2.5 \mu \mathrm{g}$ aRNA were labeled using DY-547/647 (Red - CY5 and Green CY3) fluorescent dyes from a Universal
Linkage System (ULS) Labeling Kit (EA-006, Kreatech Diagnostics, Amsterdam, The Netherlands) according to the manufacturer's protocol. With the intent of removing all nonreacted ULS-labeled material, another round of purification was performed on the labeled aRNA, also using the Pico-Pure RNA Isolation Kit but without DNAse I treatment. Pure labeled aRNA was eluted with $11 \mu$ l elution buffer. Labeling efficiency was measured using NanoDrop ND-1000. A minimum of $30 \mathrm{pmol} / \mu \mathrm{g}$ (dye concentration/aRNA concentration) of labeling signal was required to proceed with hybridization. A hybridization mixture was prepared using $825 \mathrm{ng}$ of each cyanine (Cy3 and Cy5) labeled amplified aRNA, Agilent and tomato spikes, nuclease-free water, $10 \times$ blocking agent, and $a$ $25 \times$ fragmentation buffer, in a total volume of $55 \mu \mathrm{l}$, which was pipetted onto the hybridization slides. Three biological replicates in each group (superstimulation vs control) were used in the experimental design, in a dye-swap setup. Overall, six hybridizations were performed using a custom-built bovine oligo-array slide (EmbryoGENE EMBV3 manufactured by Agilent; Design ID: 028298, GEO accession \# GPL13226). The slide contained a total of 45220 oligonucleotide probes. Each probe had a duplicate and the slide also included Agilent's positive and negative controls in $4 \times 44 \mathrm{~K}$ format. Oligo sequences were taken from the Oligo Microarray Consortium database (BOMC, http://www.bovineoligo.org).

Hybridizations were performed using $2 \times$ GEx Hybridization Buffer HI-RPM (Agilent Technologies, Wilmington, DE, USA) at $65^{\circ} \mathrm{C}$ in a preheated oven for $17 \mathrm{~h}$ with a rotator speed of $0.05 \mathrm{~g}$ Slides were washed with two buffers from the gene expression wash buffer kit (Agilent technologies, Inc., Catalog \# 5188-5327) according to the manufacturer's protocol. Later, slides were dipped in $100 \%$ acetonitrile for $10 \mathrm{~s}$ at room temperature and washed with stabilization and drying solution for $30 \mathrm{~s}$ at room temperature.

The slides were scanned immediately and visualized using a Power Scanner (Tecan US, Inc., Durham, NC, USA). After image acquisition, scanned images were analyzed and quantified using Array-Pro Analyzer software (Media Cybernetics, Silver Spring, MD, USA).

\section{Data normalization and statistical analysis}

Raw signal intensity files were uploaded to the EmbryoGENE laboratory information management system and microarray analysis platform. Quality of hybridization was evaluated using Gydle software (http://www.gydle.com/). Signal intensity data were analyzed using the FlexArray software, version 1.6.1 (Blazejczyk et al. 2007). The intensity of the background signal was subtracted from the median gray-scale value of the spot in question to obtain corrected signal intensity. If the background intensity was higher than the signal intensity for a spot, the negative value was replaced with 0.5 as a default. Data were normalized within and between arrays using Loess and Quantile normalization methodology (GEO \#: GSE45381) respectively (Bolstad et al. 2003). Linear Models for Microarray (Limma) data analysis was performed (implemented in FlexArray software; http://genomequebec.mcgill.ca/FlexArray/ license.php) to obtain differentially expressed genes in the superstimulation group compared with the reference 
(unstimulated control) group (Smyth 2004, 2005) using a fold change of $\geq 2$ and a $P$ value of $\leq 0.05$ as a threshold. To identify true positive gene changes, a false discovery rate analysis was done using the Benjameni-Hochberg method (Benjamini \& Hochberg 1995) with a fold change of $\geq 2$ and a $P$ value of $\leq 0.05$.

\section{Functional annotation and pathway analysis}

The list of differentially expressed gene, generated after Limma analysis, was uploaded into Ingenuity Pathways Analysis software (IPA; Ingenuity Systems, www.ingenuity.com) to identify gene networks. Gene networks were used to identify likely biological functions, molecular processes and disorders, and pathways most related to the gene list. IPA analyses are based on human and mouse studies.

\section{Real-time PCR}

Based on the results of microarray data, five genes (neurotensin $(N T S), F B J$ murine osteosarcoma viral oncogene homolog (FOS), thrombospondin 1 (THBS1), fibronectin 1 (FN1), and insulin-like growth factor 2 (IGF2)) were selected for validation with real-time PCR. The selected genes were involved in the hypotheses generated on the basis of the results of the microarray analysis. Primers were designed using Primer3 v.0.4.0 website (http://frodo.wi.mit.edu/primer3/) and analyzed using IDT PrimerQuest tool - Oligo Analyzer (http:// scitools.idtdna.com/analyzer/Applications/OligoAnalyzer/), and BLAST analysis was performed using NCBI database (http:// www.ncbi.nlm.nih.gov/tools/primer-blast/index.cgi?LINK_ LOC = BlastHome; http://blast.ncbi.nlm.nih.gov/Blast.cgi? PROGRAM = blastn\&BLAST_PROGRAMS = megaBlast $\&$ PA GE_TYPE $=$ BlastSearch \&SHOW_DEFAULTS = on\&LINK_ $\mathrm{LOC}=$ blasthome). Selected primers were specific to the gene of interest and met the following criteria: 20-24 bp; 55-65 ${ }^{\circ} \mathrm{C}$ melting temperature; $40-60 \%$ CG content; and no hairpin, self-dimer, or hetero-dimer formation. Nucleotide sequences of selected forward and reverse primers are presented in Table 1 and primers were synthesized by a commercial company (Integrated DNA Technologies (IDT), Inc., Coralville, IA, USA). Primers were tested by performing real-time PCR of cDNA from pooled granulosa cell samples. The amplicon was separated by electrophoresis on a standard $1 \%$ agarose gel to determine the size of the band. The band was cut and eluted using a QIAquick Gel Extraction kit (Catalog \# 28704, Qiagen), quantified using NanoDrop ND-100, and sequenced using an ABI 3730xI DNA Analyzer. Primers were used only if the amplicon sequence matched the desired gene of interest. The amplicon was used for generating a standard curve. The range of the standard curve was $10^{-2}-10^{-11} \mathrm{ng} / \mu \mathrm{l}$. Realtime PCR was performed on a Stratagene Mx3005P fast thermal cycler (Applied Bioscience) using SYBR Green master mix (Applied Bioscience). The cycle threshold was recorded, and expression of the gene of interest was normalized to a geometric mean of three reference genes (UBE2D2, EIF2B2, and SF3A1) using the Relative Expression Software Tool (REST 2009, Qiagen).
Table 1 Primers used for real-time PCR.

\begin{tabular}{|c|c|c|c|}
\hline Genes & Strand & Primer sequence & $\begin{array}{c}\text { Annealing } \\
\text { temperature } \\
\left({ }^{\circ} \mathrm{C}\right)\end{array}$ \\
\hline \multirow[t]{2}{*}{ EIF2B2 } & Forward & $\begin{array}{l}\text { 5'-CATGAGATGGCAGT- } \\
\text { CAATTTGT-3' }\end{array}$ & 53.6 \\
\hline & Reverse & $\begin{array}{l}\text { 5'-CTTGAACATAGGAGCACA- } \\
\text { GACG-3' }\end{array}$ & 55.5 \\
\hline \multirow[t]{2}{*}{ SF3A1 } & Forward & $\begin{array}{l}\text { 5'-TGTGTCCCTCTTGCTG- } \\
\text { AGTTT-3' }\end{array}$ & 56.4 \\
\hline & Reverse & $\begin{array}{l}\text { 5'-ATTCCTGGTTT- } \\
\text { CACGTCTCCTA-3' }\end{array}$ & 55.5 \\
\hline \multirow[t]{2}{*}{ UBE2D2 } & Forward & $\begin{array}{l}\text { 5'-TGGACTCAGAAGTATGC- } \\
\text { GATGT-3' }\end{array}$ & 55.8 \\
\hline & Reverse & $\begin{array}{l}\text { 5'-CTTCTCTGCTAGGAGG- } \\
\text { CAATGT-3' }\end{array}$ & 56.6 \\
\hline \multirow[t]{2}{*}{ NTS } & Forward & $\begin{array}{l}\text { 5'-AGTGTTCCCTCTTG- } \\
\text { GAAAATGA-3' }\end{array}$ & 60 \\
\hline & Reverse & 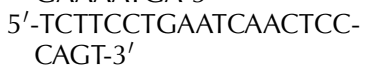 & 60.1 \\
\hline \multirow[t]{2}{*}{ FOS } & Forward & $\begin{array}{l}\text { 5'-AGGTAGAACAGTTGTCCC- } \\
\text { CAGA-3' }\end{array}$ & 60 \\
\hline & Reverse & $\begin{array}{l}\text { 5'-CAAAGCCGACTTCT- } \\
\text { CATCTTCT-3' }\end{array}$ & 60 \\
\hline \multirow[t]{2}{*}{ THBS1 } & Forward & $\begin{array}{l}\text { 5'-TCGACTGTGAGAAGATG- } \\
\text { GAGAA-3' }\end{array}$ & 59.9 \\
\hline & Reverse & $\begin{array}{l}\text { 5'-GTTGTCAAGGGTGA- } \\
\text { CAAAGACA-3' }\end{array}$ & 60 \\
\hline \multirow[t]{2}{*}{ FN1 } & Forward & $\begin{array}{l}\text { 5'-AGAAGAGTGAGCCTTT- } \\
\text { GATTGG-3' }\end{array}$ & 59.9 \\
\hline & Reverse & $\begin{array}{l}\text { 5'-AGATCATTTGTTGCCCAA- } \\
\text { GACT-3' }\end{array}$ & 60 \\
\hline \multirow[t]{2}{*}{ IGF2 } & Forward & $\begin{array}{l}\text { 5'-GCAACACCAGAAAAG- } \\
\text { CAAACTA-3' }\end{array}$ & 59.4 \\
\hline & Reverse & $\begin{array}{l}\text { 5'-CAGATCCAAAAGGAAC- } \\
\text { GAGAAG-3' }\end{array}$ & 60.2 \\
\hline
\end{tabular}

\section{RIA}

Estradiol $\left(E_{2}\right)$ and progesterone $\left(P_{4}\right)$ concentrations were measured in samples of antral fluid aspirated from superstimulated follicles and from dominant and subordinate follicles in the control group by RIAs. Slaughterhouse ovaries were used to obtain a charcoal-extracted pool of follicular fluid, which was used to prepare the standards and dilute follicular fluid samples. The standard curve ranged from 5 to $1000 \mathrm{pg} / \mathrm{ml}$ for $\mathrm{E}_{2}$ and 0.1 to $40 \mathrm{ng} / \mathrm{ml}$ for $\mathrm{P}_{4}$. Samples were diluted using the charcoal-extracted pooled follicular fluid so that hormone concentrations fell within the limits of the standard curve and samples were assayed in duplicates. $E_{2}$ was measured with a modified human double-antibody RIA kit (Catalog \# KE2D1, Coat-A-Count; Siemens Healthcare Diagnostics, Inc., Mississauga, ON, Canada), dilutions ranged from $1: 25$ to $1: 500$. $\mathrm{P}_{4}$ was measured using a commercial RIA kit (Catalog \# TKOP1, Coat-A-Count; Siemens Healthcare Diagnostics, Inc.) and all samples were diluted 1:10. All samples for $\mathrm{P}_{4}$ analysis were analyzed in a single assay only and the intraassay coefficient of variation was $5.6 \%$. $E_{2}$ was measured in two different assays and the intra-assay coefficient of variation was $11 \%$, while the interassay coefficient of variation was $8.1 \%$. Hormone data were analyzed by ANOVA using a general linear model procedure (GLM; SAS Learning Edition 4.1; SAS Institute, Cary, NC, USA) to compare follicular fluid from the 
superstimulation group vs dominant follicle from non-superstimulated (control group) vs the subordinate follicles from non-superstimulated (control group) animals.

\section{Results}

\section{Differential gene expression profile}

A total of 470 genes were differentially expressed in granulosa cells from superstimulated cows compared with those of untreated control cows. Of these, 190 genes had significantly lower expression in the superstimulated group (i.e. downregulated genes), and 280 genes had significantly higher expression in the superstimulated group (i.e. upregulated genes) compared with controls (Fig. 2). The ten most upregulated and downregulated genes in the superstimulation vs control group are listed in Table 2.

\section{Function, network, and pathway analyses}

Cellular functions most affected by superstimulation treatment were cellular growth and development (Fig. 3A). Regarding disease and disorders, superstimulation activated genes related to cancer, genetic disorders, and disorders of the cardiovascular system (Fig. 3B). Network analysis identified a network of processes involving matrix-remodeling, more specifically genes involved in proliferation of cells, apoptosis, and angiogenesis (Fig. 4). The most significant canonical pathways identified by Inguinity pathway analysis were those related to IGF1 (IGF) and MAPK7 (ERK5) signaling, oxidative stress response, and inhibition of angiogenesis (Fig. 5).

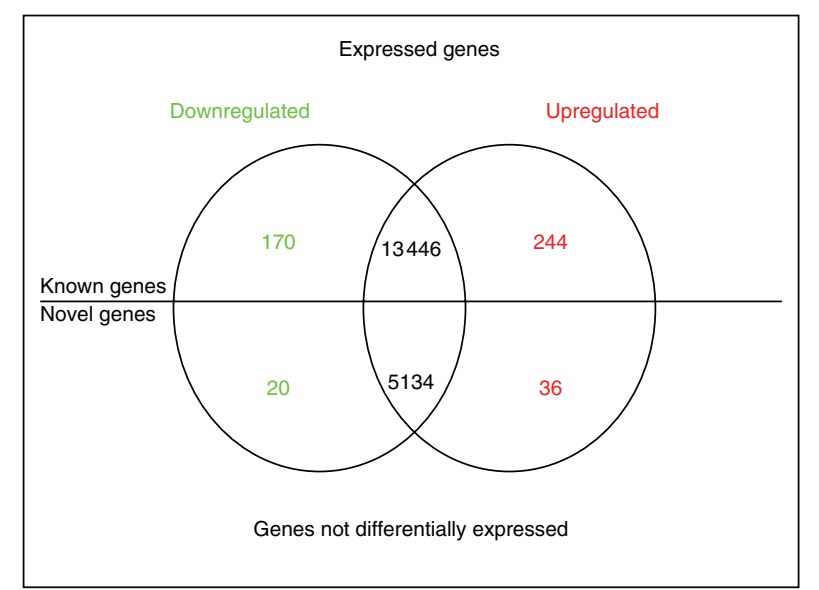

Figure 2 Venn diagram summarizing microarray analysis of granulosa cells of follicles from superstimulated vs untreated control cows. Detected signals were those that were $\geq 2$ s.D. above the background (mean \pm s.D. of background, 129.8 \pm 14.9 ). Linear Models for Microarray Data (Limma) was used for statistical analysis, and upregulated and downregulated genes were determined using a fold change of $\geq 2$ and a $P$ value of $\leq 0.05$.
Table 2 Top ten upregulated and downregulated genes in granulosa cells of beef cows after ovarian superstimulation treatment compared with untreated controls ( $n=3$ cows per group).

\begin{tabular}{|c|c|c|c|}
\hline Genes & Description & $\begin{array}{c}\text { Fold } \\
\text { change }\end{array}$ & $P$ value \\
\hline \multicolumn{4}{|l|}{ Upregulated } \\
\hline NTS & Neurotensin & 9.987 & $9.13 \times 10^{-7}$ \\
\hline$S 100 B$ & S100 calcium binding protein B & 8.345 & $8.43 \times 10^{-3}$ \\
\hline IGFBP1 & IGF binding protein 1 & 7.797 & $2.03 \times 10^{-3}$ \\
\hline GFPT2 & $\begin{array}{l}\text { Glutamine-fructose-6-phosphate } \\
\text { transaminase } 2\end{array}$ & 7.777 & $8.23 \times 10^{-3}$ \\
\hline SLC39A8 & $\begin{array}{l}\text { Solute carrier family } 39 \\
\quad \text { (zinc transporter), member } 8\end{array}$ & 7.775 & $4.53 \times 10^{-4}$ \\
\hline COBLL1 & Cordon-bleu protein-like 1 & 7.35 & $7.07 \times 10^{-3}$ \\
\hline FOS & $\begin{array}{l}\text { FBJ murine osteosarcoma viral } \\
\text { oncogene homolog }\end{array}$ & 6.86 & $1.27 \times 10^{-5}$ \\
\hline LUM & Lumican & 6.006 & $5.27 \times 10^{-4}$ \\
\hline RCAN1 & Regulator of calcineurin 1 & 5.892 & $2.76 \times 10^{-4}$ \\
\hline THBS1 & Thrombospondin 1 & 5.685 & $1.71 \times 10^{-3}$ \\
\hline \multicolumn{4}{|l|}{ Downregulated } \\
\hline FES & Feline sarcoma oncogene & 7.638 & $1.85 \times 10^{-3}$ \\
\hline$N R P 1$ & Neuropilin 1 & 6.482 & $2.16 \times 10^{-5}$ \\
\hline $\begin{array}{l}\text { SOWAHA } \\
\text { (ANKRD43) }\end{array}$ & Ankyrin repeat domain 43 & 5.517 & $3.52 \times 10^{-4}$ \\
\hline $\mathrm{CN} / \mathrm{H} 3$ & $\begin{array}{l}\text { Cornichon homolog } 3 \\
\quad \text { (Drosophila) }\end{array}$ & 4.944 & $1.89 \times 10^{-4}$ \\
\hline MGST2 & $\begin{array}{l}\text { Microsomal glutathione } \\
\text { S-transferase } 2\end{array}$ & 4.687 & $4.36 \times 10^{-4}$ \\
\hline ANGPT2 & Angiopoietin 2 & 4.53 & $3.69 \times 10^{-2}$ \\
\hline$L T F$ & Lactotransferrin & 4.524 & $1.35 \times 10^{-4}$ \\
\hline TRIB2 & Tribbles homolog 2 (Drosophila) & 4.472 & $8.34 \times 10^{-3}$ \\
\hline SYNE1 & $\begin{array}{l}\text { Spectrin repeat containing, } \\
\text { nuclear envelope } 1\end{array}$ & 4.467 & $7.13 \times 10^{-3}$ \\
\hline$M X R A 8$ & Matrix-remodeling associated 8 & 4.289 & $7.35 \times 10^{-3}$ \\
\hline
\end{tabular}

\section{Real-time PCR validation}

Based on microarray data and function analysis, five genes were selected for validation with real-time PCR (i.e. NTS, FOS, FN1, THBS1, and IGF2). After quantification in three independent biological replicates from superstimulation and control groups, differential expression was validated for four of the five genes $(90 \%$ $\mathrm{Cl} ; P \leq 0.1$; Fig. 6).

\section{Hormone levels in follicular fluid}

Follicular fluid from superstimulated follicles and from dominant follicles of the control group had a higher $\mathrm{E}_{2}$ levels compared with subordinate follicles of the control group $(153.8 \pm 32.7,160.4 \pm 64.9$, and $0.05 \pm 0.02 \mathrm{ng} / \mathrm{ml}$; mean \pm S.E.M. respectively; $P=0.01)$. Follicular fluid $\mathrm{P}_{4}$ levels did not differ among groups $(99.8 \pm 19.7,74.0 \pm 18.5$, and 108.6 $\pm 62.7 ; P=0.8 \mathrm{ng} / \mathrm{ml}$; mean \pm S.E.M. respectively; $P=0.8) . E_{2}: P_{4}$ ratio was greater in follicular fluid from superstimulated follicles and from dominant follicles of the control group compared with subordinate follicles of the control group $(3.5 \pm 0.8,2.2 \pm 1.2$, and $0.004 \pm 0.002$; mean \pm s.E.M. respectively; $P=0.03$ ); however, the ratio did not differ between the superstimulated follicles and the dominant follicle. 

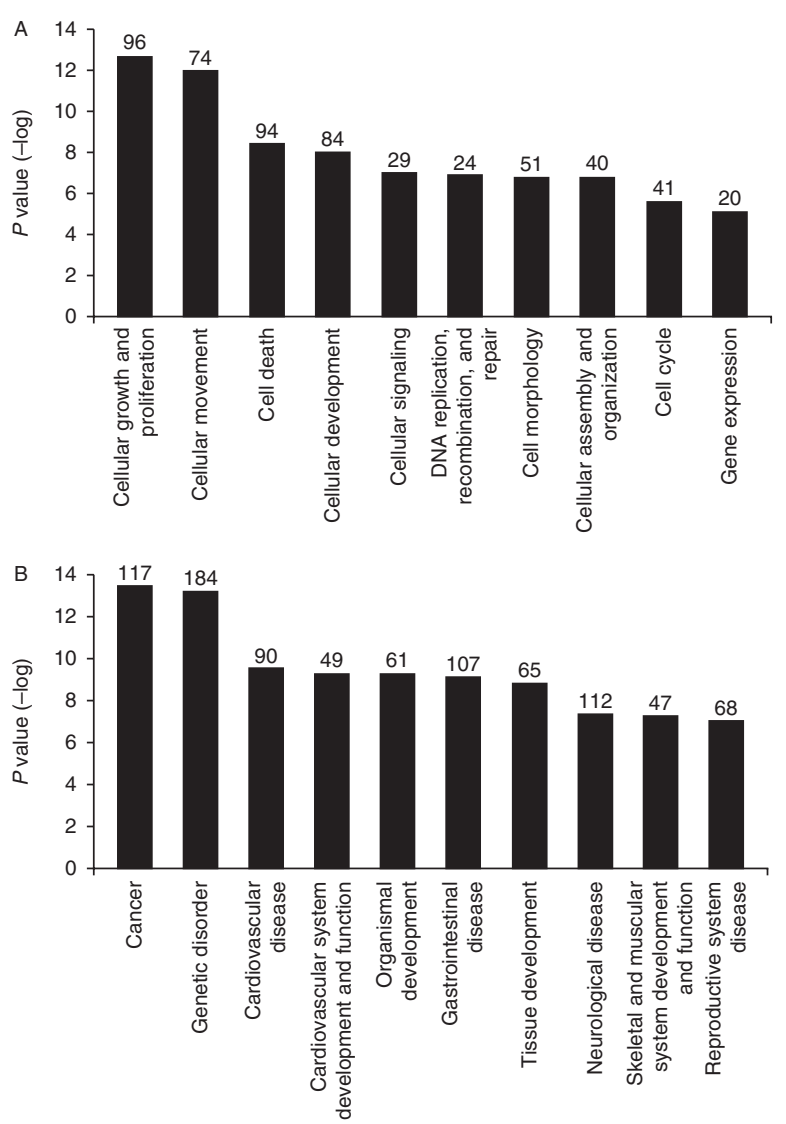

Figure 3 Function analysis of gene expression of granulosa cells after superstimulation treatment based on log $P$ value. The higher the log $P$ value (taller bars), the more significant the function is. Numbers at the top of the bars indicate number of genes involved in each function. The top ten molecular and cellular functions (A) and top ten diseases and disorders/roles in physiological system development and function (B) are illustrated.

\section{Discussion}

Ovarian superstimulation protocols are used widely in monovular species as a component of assisted reproductive technologies. Superstimulation involves the use of $\mathrm{FSH}$ to stimulate continued growth of a follicular cohort to a pre-ovulatory stage. The effect of superstimulation on follicular dynamics in cattle is well known (Adams et al. 1992, Nasser et al. 1993, Adams 1998, Mapletoft et al. 2002); however, the genomic response of bovine follicles to gonadotropin stimulation has not been established. Results of this study indicate that molecular pathways related to granulosa cell differentiation are altered in superstimulated follicles compared with dominant follicles of unstimulated follicular waves at an equivalent stage of development (that is, identical durations from wave emergence to $\mathrm{P}_{4}$ withdrawal and exogenous LH treatment and identical post-LH period). The results provide a rationale for three hypotheses: compared with the granulosa cells of single (natural) dominant follicles, superstimulation treatment i) results in granulosa cells that lag behind in maturation and differentiation (most of the upregulated genes are markers of the follicular growth stage), ii) activates genes involved with the oxidative stress response, and iii) disturbs angiogenesis.

Compared with a single dominant follicle of a naturally occurring follicular wave, ovarian superstimulatory treatment delays selection and results in development of multiple dominant follicles (Adams et al. 1993b). However, results of this study suggest that the multiple pre-ovulatory follicles that develop after superstimulation are not typical dominant follicles. The list of upregulated genes in the superstimulation group in this study is similar to those of other studies (Gilbert et al. 2011 , 2012) from dominant follicles before the LH surge at day 14 of the estrous cycle. It is important to note that the granulosa cells from our superstimulation group were collected $24 \mathrm{~h}$ after exogenous $\mathrm{LH}$ surge (i.e. close to the expected time of ovulation). The principal molecular functions altered by ovarian superstimulation were those associated with cell growth and proliferation, providing a rationale for the hypothesis that superstimulation delays granulosa cell differentiation. That is, the granulosa layers of single pre-ovulatory follicles at the time of collection have differentiated beyond the growing stage by downregulating genes associated with cell growth and proliferation and/or perhaps responding better to LH signaling compared with the granulosa cells from superstimulated follicles. It would be interesting to determine whether delaying the LH surge after superstimulation treatment would result in follicular maturation and a better fertility outcome. It is worth noting that not all functions are equally affected, e.g. steroidogenic function (intrafollicular $\mathrm{E}_{2}$ concentration, $\mathrm{E}_{2}: \mathrm{P}_{4}$ ratio) was very similar between the dominant and superstimulated follicles.

The extracellular matrix plays a prominent role in ovarian function by participating in processes such as cell migration, proliferation, growth, and development of follicles (Berkholtz et al. 2006a, 2006b). In this study, upregulated genes involved with remodeling of the extracellular matrix included NTS, FOS, THBS1, FN1, ADAMTS1, connective tissue growth factor $(C T G F)$, genes from the IGF family, and those involved in collagen formation. A specific network was built to show how extracellular matrix-remodeling genes interact with each other and how superstimulation affected this process (Fig. 4).

The NTS gene encodes a tridecapeptide, NTS, found in the hypothalamus. NTS is known to mediate the positive feedback of $E_{2}$ on the gonadotrophin-releasing hormone $(\mathrm{GNRH})$ neurons responsible for inducing the pre-ovulatory LH surge (Smith \& Jennes 2001). NTS was thought to be localized exclusively in the nervous system, but results of recent studies document the presence of NTS mRNA in the ovaries (Hernandez-Gonzalez et al. 2006, Kerr et al. 2009, Gilbert et al. 2011). 


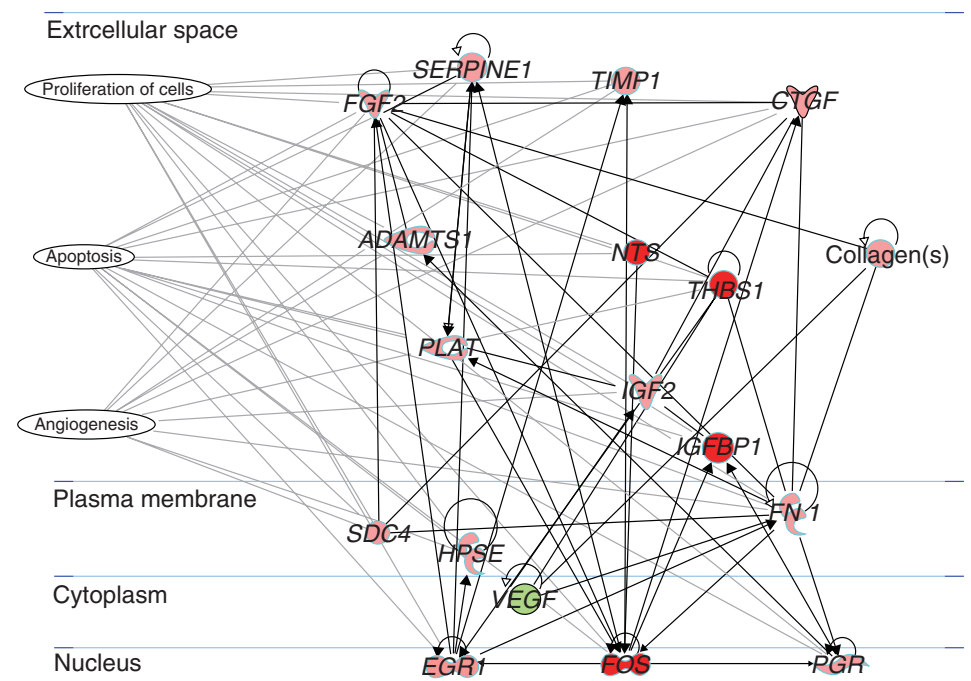

Figure 4 Network of genes upregulated or downregulated in granulosa cells after ovarian superstimulation in cattle. All genes involved in this network are part of the matrix-remodeling network; more specifically, cellular proliferation ( $n=16$ genes), apoptosis $(n=15$ genes), and angiogenesis ( $n=11$ genes). Genes are arranged into four horizontal compartments (nucleus, cytoplasm, plasma membrane, and extracellular space) based on the subcellular location of their gene products. The differences in color intensity of molecules show the degree of up- (red) or down(green) regulation and connecting lines indicate a known relationship between molecules. The genes found to be upregulated were early growth response 1 (EGR1), FBJ murine osteosarcoma viral oncogene homolog (FOS), progesterone receptor (PGR), syndecan 4 (SDC4), heparanase (HPSE), fibronectin 1 (FN1), insulin-like growth factor binding protein 1 (IGFBP1), insulin-like growth factor 2 (IGF2), plasminogen activator tissue (PLAT), a disintegrin and metalloprotease metallopeptidase 1 (ADAMTS1), neurotensin (NTS), thrombospondin 1 (THBS1), collagens, fibroblast growth factor 2 (FGF2), serpin peptidase inhibitor class E member 1 (SERPINE1), metallopeptidase inhibitor 1 (TIMP1) and connective tissue growth factor (CTGF). The only downregulated gene was vascular endothelial growth factor (VEGF). The genes included transcription regulators (EGFR and FOS), ligand-dependent nuclear receptors (PGR), cytokine or growth factors (FGF2, CTGF, and IGF2), peptidases (ADAMTS1 and PLAT), enzymes (HPSE and FN1) or other (VEGF, SERPINE, SDC4, TIMP1, NTS, THBS1, collagens, and IGFBP1) categories.

Little is known about the role of NTS in ovarian cells, but expression of NTS mRNA in granulosa and cumulus cells is high before the LH surge and decreases thereafter as ovulation approaches (Hernandez-Gonzalez et al. 2006, Gilbert et al. 2011). Based on the RT-PCR analysis, NTS was upregulated 7.6-fold (10-fold in microarrays data) after ovarian superstimulation, suggesting that treatment is associated with delay in cell differentiation and/or delayed follicular response to the LH surge. FOS (6.9fold in microarray data and 8.1-fold in RT-PCR) and FOSL1 (2.1-fold in microarrays) transcriptions were also upregulated, and both activate NTS synthesis (Evers et al. 1995). Expression of FOS has been associated with cell proliferation and development (Delidow et al. 1990) and FSH rapidly increases FOS expression in immature rat granulosa cells (Delidow et al. 1992). Expression of FOS decreases with luteinization (Rusovici \& LaVoie 2003) and is already low in bovine granulosa cells by $6 \mathrm{~h}$ after the LH surge (Gilbert et al. 2011). Therefore, we conclude that granulosa cells of superstimulated follicles were either unable to shut down NTS, FOS, and FOSL1 transcription or at least were slower to respond to exogenous $\mathrm{LH}$.

CTGF has also been implicated in tissue remodeling. CTGF mRNA is expressed abundantly in granulosa cells of pre-antral and early antral follicles in rats (Harlow et al. 2002) and pigs (Wandji et al. 2000), but its expression is downregulated in pre-ovulatory follicles in both species. Expression of CTGF is influenced by local estrogen, which in turn is modulated by the effect of FSH on granulosa cells (Harlow et al. 2007). Perhaps expression of CTGF will be a useful marker for granulosa cell maturity as many studies have reported an inverse relationship between CTGF expression and granulosa cell differentiation (Wandji et al. 2000, Harlow \& Hillier 2002, Harlow et al. 2002, Liu et al. 2002, Schindler et al. 2010). Although the follicular fluid concentrations of $E_{2}$ were similar between the two groups in this study, CTGF was upregulated in the granulosa cells of superstimulated follicles, again showing a delay in follicular maturation. Further, expression of three other genes involved in matrix remodeling, SERPINE, FN1, and IGF2 was also elevated in the superstimulation group. SERPINE is downregulated in bovine granulosa cells after LH treatment (Gilbert et al. 2012) and FN1 expression is reported to be inversely related to follicle maturation (Colman-Lerner et al. 1999, Yasuda et al. 2005, Berkholtz et al. 2006b). IGF proteins are produced by the granulosa cells and have been shown to have a synergetic effect with $\mathrm{FSH}$ to induce cellular growth and proliferation (Hammond et al. 1985). The expression of IGF2 is increased in follicles collected on day 5 $(\mathrm{D} 0=$ ovulation) and decreased in follicles at day 8 (de la Sota et al. 1996). The increased expression of the genes described earlier reflect the fact that matrix remodeling is active, probably due to follicular grow. 


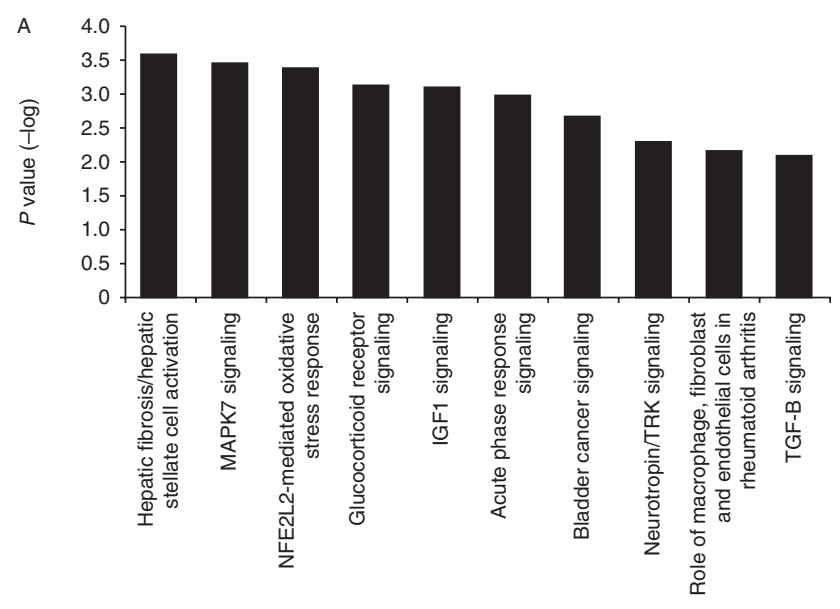

Timp1 is increased up to $4 \mathrm{~h}$ after hCG treatment in granulosa cells of immature PMSG-primed rat ovaries and gradually decreases afterward (Li \& Curry 2009). It is interesting to note that HPSE, PLAT, and TIMP1 expression was higher in superstimulated follicles. In contrast, EGR1 expression is expected to decrease near the time of ovulation (Sayasith et al. 2006) but failed to be downregulated in superstimulated follicles. Overexpression of EGR1 stimulated the expression of many genes in the prostaglandin biosynthesis pathway and increased expression of $\mathrm{LH}$ receptor mRNA (Sayasith et al. 2006). Its expression in superstimulated follicles from women was associated with increased oocyte competence (Hamel et al. 2008). It is apparent from our results that expressions of some but not all genes involved in the ovulatory cascade are affected by superstimulation. In this study, LH was given $24 \mathrm{~h}$ after the end of superstimulation treatment. Perhaps the exogenous $\mathrm{LH}$ is driving follicles that are not fully matured to reach the pre-ovulatory molecular stage and ovulate. However, this hypothesis needs to be further investigated.

In this study, genes related to the stress response (Fig. 5) were activated in granulosa cells from superstimulated follicles. Our results are supported by similar findings in embryos from superstimulated donors (Mundim et al. 2009), where genes related to oxidative stress response tended to be activated. In this study, the NFE2L2 oxidative stress response pathway was one of the most activated pathways in the superstimulation group. NFE2L2 interacts with other transcription factors

Figure 5 Canonical pathway analyses of gene expression of granulosa cells after superstimulation treatment using Ingenuity Pathway Analysis software (IPA). (A) Top ten pathway analyses based on $-\log 10 P$ value. (B) Top ten pathway analyses based on a score ratio. The score ratio was calculated by IPA and is the number of differentially expressed molecules in the gene list/number of genes known to be involved in the pathway.

Matrix remodeling is not only important in follicle growth and development but also during ovulation and CL formation (Berkholtz et al. 2006a). In this study, some upregulated genes in the matrix-remodeling network (HPSE, early growth response 1 (EGR1), tissue inhibitor metalloproteinase 1 (TIMP1), and plasminogen activator $(P L A T))$ are markers of the initiation of ovulatory process (Gilbert et al. 2011, 2012). HPSE encodes heparanase that cleaves heparan sulfate (one of the tissue glycosaminoglycans) during matrix remodeling and is highly expressed in bovine granulosa cells $12 \mathrm{~h}$ after GNRH treatment. Heparanase was suggested to be a novel member of the LH-induced ECM-degrading enzyme family involved with follicular rupture (Klipper et al. 2009). Likewise, PLAT creates functionally redundant mechanisms for plasmin formation during ovulation (Sayasith et al. 2006) and is highly expressed in granulosa cells of pre-ovulatory follicles in rats (Galway et al. 1990, Leonardsson et al. 1995). The expression of

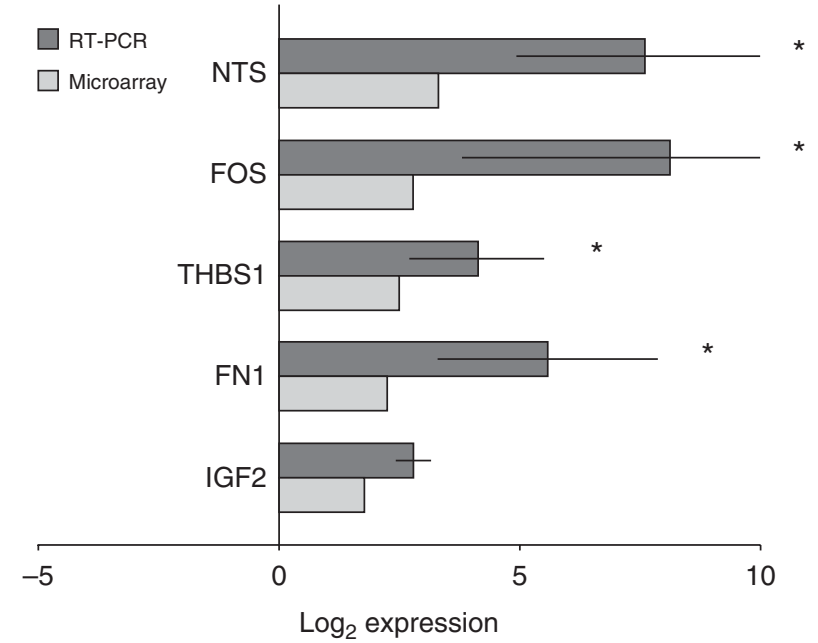

Figure 6 Quantification ( $\log _{2}$ of fold change; mean \pm S.E.M.) of the mRNA profile of granulosa cells from cows after superstimulation treatment compared with negative control (no superstimulation) using real-time PCR ( $n=3$ cows per group). Light gray bars represent the differential level of expression of transcripts detected in the microarray experiment, while dark gray bars represent the differential level of expression of the same transcripts obtained by real-time PCR. *Values are greater in the superstimulation group than in the untreated control group $(P \leq 0.1)$. 
activate antioxidant response elements (Gudi et al. 2000) to balance the oxidation level of the intracellular environment (Huang et al. 2000). The endoplasmic reticulum (ER) stress pathway was also activated in granulosa cells of superstimulated follicles in this study. Many diseases are associated with cellular stress responses, one of which is cancer (Cerutti 1989), which was identified in the top disease and disorder functions list. Perhaps the oxidative stress response comes from there being too many follicles to be supported by the ovarian vasculature. However, this hypothesis should be further tested.

Some of the upregulated genes in this study such as FOS, FN1, EGR1, SDC4, and THBS1 have been demonstrated to induce the expression of pro-apoptotic proteins (Delidow et al. 1990, Sakata et al. 2000, Yasuda et al. 2005, Hou et al. 2008, Garside et al. 2010a). THBS1 encodes a glycoprotein, thrombospondin 1, that is a component of the extracellular matrix. Thrombospondin mainly acts as anti-angiogenic factor; however, it also promotes atresia of rat granulosa cells in vitro (Garside et al. 2010a, 2010b). THBS1 is highly expressed in small follicles from bovine ovaries (Greenaway et al. 2005) as well as in small and atretic follicles of many other species (Thomas et al. 2008, Garside et al. 2010b, Zalman et al. 2012). Igf1 inhibits Thbs1 transcription in cultured rat granulosa cells and its expression is further lowered when FSH is added in culture (Dreyfus et al. 1992, McGray et al. 2011). In contrast, thrombospondin 1 is highly expressed in bovine granulosa cells when FSH is added in culture but LH had no effect (Greenaway et al. 2005). THBS1 expression was upregulated (4.1fold according to RT-PCR and 5.7-fold in microarrays) in superstimulated follicles. Perhaps expression of this group of genes indicates that even though superstimulation rescued follicles from atresia, some molecules involved with that pathway are still being triggered. In contrast, other known anti-atresia markers (ADAMTS1 and $T I M P$ ) were also upregulated after superstimulation. The protein encoded by Adamts 1 is known to prevent atresia as mice with Adamts1-null ovaries had many unusual atretic follicles (Shozu et al. 2005), demonstrating the importance of this gene in granulosa cell health. Proteins from the TIMP gene family are also known to be stimulated by FSH and to prevent atresia (Goldman et al. 1997). Therefore, superstimulation prevents atresia by increasing expression of some, but not all, anti-apoptotic genes.

Superstimulation treatment in this study influenced genes involved in angiogenesis, i.e. VEGF family, angiopoietin 2, and THBS1. Expression of angiogenic factors has been reported to be stage-dependent in granulosa cells, increasing during pre-ovulatory stage (Christenson \& Stouffer 1997, Laitinen et al. 1997, Hazzard et al. 1999, Schams et al. 2001, Reisinger et al. 2007, Shimizu et al. 2007, Berisha et al. 2008), but the molecular mechanisms involved are not fully known. Angiopoietin 2 destabilizes vascular structures and induces vascular remodeling (Yancopoulos et al. 2000). THBS1 also encodes an anti-angiogenic protein (Greenaway et al. 2005). THBS1 inhibits VEGF levels in the ovary directly via the low-density lipoprotein receptor-related protein-1 ( $L R P 1$; Greenaway et al. 2007). Inhibition of expression of angiogenic factor (VEGF) and increased expression of anti-angiogenic factor (THBS1) was consistent with the results of pathway and function analysis wherein cardiovascular system development was identified as one of the top disease and disorder functions affected. Results suggest that angiogenesis may be inhibited, and perhaps corpus luteum formation may be disturbed after superstimulation treatment.

In conclusion, ovarian superstimulation activates genes involved in the NFE2L2 oxidative stress response, and ER stress response, apoptosis, disturbance of angiogenesis and matrix remodeling. Moreover, ovarian superstimulation was associated with upregulation of growth-related genes in follicular granulosa cells. The results are consistent with the hypothesis that follicles that undergo superstimulation lag behind in maturational development and response to $\mathrm{LH}$.

\section{Declaration of interest}

The authors declare that there is no conflict of interest that could be perceived as prejudicing the impartiality of the research reported.

\section{Funding}

This study was funded by Natural Science and Engineering Research Council of Canada (NSERC) as part of the EmbryoGENE Network.

\section{References}

Adams GP 1994 Control of ovarian follicular wave dymanics in cattle: implications for synchronization and superstimulation. Theriogenology 41 19-24. (doi:10.1016/S0093-691X(05)80044-5)

Adams GP 1998 Control of ovarian follicular wave dynamics in mature and prepubertal cattle for synchronization \& superstimulation. Proceedings of the Twentieth Congress of the World Association for Buiatrics, Sydney, New South Wales, Australia. pp 595-605.

Adams GP, Matteri RL, Kastelic JP, Ko JC \& Ginther OJ 1992 Association between surges of follicle-stimulating hormone and the emergence of follicular waves in heifers. Journal of Reproduction and Fertility 94 177-188. (doi:10.1530/jrf.0.0940177)

Adams GP, Kot K, Smith CA \& Ginther OJ 1993a Effect of the dominant follicle on regression of its subordinates in heifers. Canadian Journal of Animal Science 73 267-275. (doi:10.4141/cjas93-029)

Adams GP, Kot K, Smith CA \& Ginther OJ 1993b Selection of a dominant follicle and suppression of follicular growth in heifers. Animal Reproduction Science 30 259-271. (doi:10.1016/0378-4320(93)90076-4)

Adams GP, Nasser LF, Bo GA, Garcia A, Del Campo MR \& Mapletoft RJ 1994 Superovulatory response of ovarian follicles of Wave 1 versus Wave 2 in heifers. Theriogenology 42 1103-1113. (doi:10.1016/0093691X(94)90858-3) 
Adams GP, Jaiswal R, Singh J \& Malhi P 2008 Progress in understanding ovarian follicular dynamics in cattle. Theriogenology 69 72-80. (doi:10. 1016/j.theriogenology.2007.09.026)

Bao B \& Garverick HA 1998 Expression of steroidogenic enzyme and gonadotropin receptor genes in bovine follicles during ovarian follicular waves: a review. Journal of Animal Science 76 1903-1921.

Benjamini Y \& Hochberg Y 1995 Controlling the false discovery rate: a practical and powerful approach to multiple testing. Journal of the Royal Statistical Society 57 289-300. (doi:0035-9246/95/57289)

Berfelt DR, Lightfoot KC \& Adams GP 1994 Ovarian synchronization following ultrasound-guided transvaginal follicle ablation in heifers. Theriogenology 42 895-907. (doi:10.1016/0093-691X(94)90113-W)

Berisha B, Steffl M, Welter H, Kliem H, Meyer HH, Schams D \& Amselgruber W 2008 Effect of the luteinising hormone surge on regulation of vascular endothelial growth factor and extracellular matrix-degrading proteinases and their inhibitors in bovine follicles. Reproduction, Fertility, and Development 20 258-268. (doi:10.1071/ RD07125)

Berkholtz CB, Lai BE, Woodruff TK \& Shea LD 2006a Distribution of extracellular matrix proteins type I collagen, type IV collagen, fibronectin, and laminin in mouse folliculogenesis. Histochemistry and Cell Biology 126 583-592. (doi:10.1007/s00418-006-0194-1)

Berkholtz CB, Shea LD \& Woodruff TK $2006 b$ Extracellular matrix functions in follicle maturation. Seminars in Reproductive Medicine 24 262-269. (doi:10.1055/s-2006-948555)

Blazejczyk M, Miron M \& Nadon R 2007 FlexArray: a statistical data analysis software for gene expression microarrays. Montreal, Canada: Génome Québec (available at http://genomequebec.mcgill.ca/ FlexArray)

Bolstad BM, Irizarry RA, Anstrand M \& Speed TP 2003 A comparison of normalization methods for high density oligonucleotide array data based on variance and bias. Bioinformatics 19 185-193. (doi:10.1093/ bioinformatics/19.2.185)

Cerutti PA 1989 Mechanisms of action of oxidant carcinogens. Cancer Detection and Prevention 14 281-284.

Christenson LK \& Stouffer RL 1997 Follicle-stimulating hormone and luteinizing hormone/chorionic gonadotropin stimulation of vascular endothelial growth factor production by macaque granulosa cells from pre- and periovulatory follicles. Journal of Clinical Endocrinology and Metabolism 82 2135-2142. (doi:10.1210/jc.82.7.2135)

Colman-Lerner A, Fischman ML, Lanuza GM, Bissell DM, Kornblihtt AR \& Baranao JL 1999 Evidence for a role of the alternatively spliced ED-I sequence of fibronectin during ovarian follicular development. Endocrinology 140 2541-2548. (doi:10.1210/en.140.6.2541)

Delidow BC, White BA \& Peluso JJ 1990 Gonadotropin induction of c-fos and c-myc expression and deoxyribonucleic acid synthesis in rat granulosa cells. Endocrinology 126 2302-2306. (doi:10.1210/endo126-5-2302)

Delidow BC, Lynch JP, White BA \& Peluso JJ 1992 Regulation of protooncogene expression and deoxyribonucleic acid synthesis in granulosa cells of perifused immature rat ovaries. Biology of Reproduction 47 428-435. (doi:10.1095/biolreprod47.3.428)

Dreyfus M, Dardik R, Suh BS, Amsterdam A \& Lahav J 1992 Differentiationcontrolled synthesis and binding of thrombospondin to granulosa cells. Endocrinology 130 2565-2570. (doi:10.1210/en.130.5.2565)

Evers BM, Wang X, Zhou Z, Townsend CM Jr, McNeil GP \& Dobner PR 1995 Characterization of promoter elements required for cell-specific expression of the neurotensin/neuromedin $\mathrm{N}$ gene in a human endocrine cell line. Molecular and Cellular Biology 15 3870-3881.

Fauque P, Jouannet P, Lesaffre C, Ripoche MA, Dandolo L, Vaiman D \& Jammes H 2007 Assisted Reproductive Technology affects developmental kinetics, H19 Imprinting Control Region methylation and H19 gene expression in individual mouse embryos. BMC Developmental Biology 7 116. (doi:10.1186/1471-213X-7-116)

Galway AB, Lapolt PS, Tsafriri A, Dargan CM, Boime I \& Hsueh AJ 1990 Recombinant follicle-stimulating hormone induces ovulation and tissue plasminogen activator expression in hypophysectomized rats. Endocrinology 127 3023-3028. (doi:10.1210/endo-127-6-3023)

Garside SA, Harlow CR, Hillier SG, Fraser HM \& Thomas FH 2010a Thrombospondin-1 inhibits angiogenesis and promotes follicular atresia in a novel in vitro angiogenesis assay. Endocrinology 151 1280-1289. (doi:10.1210/en.2009-0686)
Garside SA, Henkin J, Morris KD, Norvell SM, Thomas FH \& Fraser HM $2010 \mathrm{~b}$ A thrombospondin-mimetic peptide, ABT-898, suppresses angiogenesis and promotes follicular atresia in pre- and early-antral follicles in vivo. Endocrinology 151 5905-5915. (doi:10.1210/en.20100283)

Gilbert I, Robert C, Dieleman S, Blondin P \& Sirard MA 2011 Transcriptional effect of the LH surge in bovine granulosa cells during the peri-ovulation period. Reproduction 141 193-205. (doi:10.1530/ REP-10-0381)

Gilbert I, Robert C, Vigneault C, Blondin P \& Sirard MA 2012 Impact of the LH surge on granulosa cell transcript levels as markers of oocyte developmental competence in cattle. Reproduction 143 735-747. (doi:10.1530/REP-11-0460)

Ginther OJ, Bergfelt DR, Kulick LJ \& Kot K 1999 Selection of the dominant follicle in cattle: establishment of follicle deviation in less than 8 hours through depression of FSH concentrations. Theriogenology 52 1079-1093. (doi:10.1016/S0093-691X(99)00196-X)

Goldman S, Dirnfeld M, Abramovici H \& Kraiem Z 1997 Triiodothyronine and follicle-stimulating hormone, alone and additively together, stimulate production of the tissue inhibitor of metalloproteinases- 1 in cultured human luteinized granulosa cells. Journal of Clinical Endocrinology and Metabolism 82 1869-1873. (doi:10.1210/jc.82.6.1869)

Greenaway J, Gentry PA, Feige J, LaMarre J \& Petrik JJ 2005 Thrombospondin and vascular endothelial growth factor are cyclically expressed in an inverse pattern during bovine ovarian follicle development. Biology of Reproduction 72 1071-1078. (doi:10.1095/ biolreprod.104.031120)

Greenaway J, Lawler J, Moorehead R, Bornstein P, Lamarre J \& Petrik J 2007 Thrombospondin-1 inhibits VEGF levels in the ovary directly by binding and internalization via the low density lipoprotein receptorrelated protein-1 (LRP-1). Journal of Cellular Physiology 210 807-818. (doi:10.1002/jcp.20904)

Gudi T, Casteel DE, Vinson C, Boss GR \& Pilz RB 2000 NO activation of fos promoter elements requires nuclear translocation of G-kinase I and CREB phosphorylation but is independent of MAP kinase activation. Oncogene 19 6324-6333. (doi:10.1038/sj.onc.1204007)

Hamel M, Dufort I, Robert C, Gravel C, Leveille MC, Leader A \& Sirard MA 2008 Identification of differentially expressed markers in human follicular cells associated with competent oocytes. Human Reproduction 23 1118-1127. (doi:10.1093/humrep/den048)

Hammond JM, Baranao JL, Skaleris D, Knight AB, Romanus JA \& Rechler MM 1985 Production of insulin-like growth factors by ovarian granulosa cells. Endocrinology 117 2553-2555. (doi:10.1210/endo-1176-2553)

Harlow CR \& Hillier SG 2002 Connective tissue growth factor in the ovarian paracrine system. Molecular and Cellular Endocrinology 187 23-27. (doi:10.1016/S0303-7207(01)00702-X)

Harlow CR, Davidson L, Burns KH, Yan C, Matzuk MM \& Hillier SG 2002 FSH and TGF- $\beta$ superfamily members regulate granulosa cell connective tissue growth factor gene expression in vitro and in vivo. Endocrinology 143 3316-3325. (doi:10.1210/en.2001-211389)

Harlow CR, Bradshaw AC, Rae MT, Shearer KD \& Hillier SG 2007 Oestrogen formation and connective tissue growth factor expression in rat granulosa cells. Journal of Endocrinology 192 41-52. (doi:10.1677/ joe.1.06689)

Hazzard TM, Molskness TA, Chaffin CL \& Stouffer RL 1999 Vascular endothelial growth factor (VEGF) and angiopoietin regulation by gonadotrophin and steroids in macaque granulosa cells during the peri-ovulatory interval. Molecular Human Reproduction 5 1115-1121. (doi:10.1093/molehr/5.12.1115)

Hernandez-Gonzalez I, Gonzalez-Robayna I, Shimada M, Wayne CM, Ochsner SA, White L \& Richards JS 2006 Gene expression profiles of cumulus cell oocyte complexes during ovulation reveal cumulus cells express neuronal and immune-related genes: does this expand their role in the ovulation process? Molecular Endocrinology 20 1300-1321. (doi:10.1210/me.2005-0420)

Hou X, Arvisais EW, Jiang C, Chen DB, Roy SK, Pate JL, Hansen TR, Rueda BR \& Davis JS 2008 Prostaglandin $F_{2 \alpha}$ stimulates the expression and secretion of transforming growth factor B1 via induction of the early growth response 1 gene (EGR1) in the bovine corpus luteum. Molecular Endocrinology 22 403-414. (doi:10.1210/me.2007-0272) 
Huang HC, Nguyen T \& Pickett CB 2000 Regulation of the antioxidant response element by protein kinase C-mediated phosphorylation of NF-E2-related factor 2. PNAS 97 12475-12480. (doi:10.1073/pnas. 220418997)

Jaiswal RS, Singh J \& Adams GP 2004 Developmental pattern of small antral follicles in the bovine ovary. Biology of Reproduction 71 1244-1251. (doi:10.1095/biolreprod.104.030726)

Kerr B, Garcia-Rudaz C, Dorfman M, Paredes A \& Ojeda SR 2009 NTRK1 and NTRK2 receptors facilitate follicle assembly and early follicular development in the mouse ovary. Reproduction 138 131-140. (doi:10. 1530/REP-08-0474)

Klipper E, Tatz E, Kisliouk T, Vlodavsky I, Moallem U, Schams D, Lavon Y, Wolfenson D \& Meidan R 2009 Induction of heparanase in bovine granulosa cells by luteinizing hormone: possible role during the ovulatory process. Endocrinology 150 413-421. (doi:10.1210/en.2008-0697)

Laitinen M, Ristimaki A, Honkasalo M, Narko K, Paavonen K \& Ritvos O 1997 Differential hormonal regulation of vascular endothelial growth factors VEGF, VEGF-B, and VEGF-C messenger ribonucleic acid levels in cultured human granulosa-luteal cells. Endocrinology 138 4748-4756. (doi:10.1210/en.138.11.4748)

Leonardsson G, Peng XR, Liu K, Nordstrom L, Carmeliet P, Mulligan R, Collen D \& Ny T 1995 Ovulation efficiency is reduced in mice that lack plasminogen activator gene function: functional redundancy among physiological plasminogen activators. PNAS 92 12446-12450. (doi:10. 1073/pnas.92.26.12446)

Li F \& Curry TE Jr 2009 Regulation and function of tissue inhibitor of metalloproteinase (TIMP) 1 and TIMP3 in periovulatory rat granulosa cells. Endocrinology 150 3903-3912. (doi:10.1210/en.2008-1141)

Liu J, Kosma VM, Vanttinen T, Hyden-Granskog C \& Voutilainen R 2002 Gonadotrophins inhibit the expression of insulin-like growth factor binding protein-related protein-2 mRNA in cultured human granulosaluteal cells. Molecular Human Reproduction 8 136-141. (doi:10.1093/ molehr/8.2.136)

Looney CR 1986 Superovulation in beef females. In Proceedings of the 5th Annual Convention of AETA, Fort Worth, TX, USA. pp 16-29.

Mapletoft RJ, Steward KB \& Adams GP 2002 Recent advances in the superovulation in cattle. Reproduction, Nutrition, Development 42 601-611. (doi:10.1051/rnd:2002046)

McGray AJ, Gingerich T, Petrik JJ \& LaMarre J 2011 Rapid insulin-like growth factor-1-induced changes in granulosa cell thrombospondin-1 expression in vitro. Journal of Reproduction and Development 57 76-83. (doi:10.1262/jrd.10-045H)

Mundim TCD, Ramos AF, Sartori R, Dode MAN, Melo EO, Gomes LFS, Rumpf R \& Franco MM 2009 Changes in gene expression profiles of bovine embryos produced in vitro, by natural ovulation, or hormonal superstimulation. Genetics and Molecular Research 8 1398-1407. (doi:10.4238/vol8-4gmr646)

Nasser LF, Adams GP, Bo GA \& Mapletoft RJ 1993 Ovarian superstimulatory response relative to follicular wave emergence in heifers. Theriogenology 40 713-724. (doi:10.1016/0093-691X(93)90207-L)

Reisinger K, Baal N, McKinnon T, Munstedt K \& Zygmunt M 2007 The gonadotropins: tissue-specific angiogenic factors? Molecular and Cellular Endocrinology 269 65-80. (doi:10.1016/j.mce.2006.11.015)

Rossignol S, Steunou V, Chalas C, Kerjean A, Rigolet $M$, ViegasPequignot E, Jouannet P, Le Bouc Y \& Gicquel C 2006 The epigenetic imprinting defect of patients with Beckwith-Wiedemann syndrome born after assisted reproductive technology is not restricted to the $11 \mathrm{p} 15$ region. Journal of Medical Genetics 43 902-907. (doi:10.1136/jmg.2006.042135)

Rusovici R \& LaVoie HA 2003 Expression and distribution of AP-1 transcription factors in the porcine ovary. Biology of Reproduction 69 64-74. (doi:10.1095/biolreprod.102.013995)

Sakata M, Kobayashi H, Sun GW, Mochizuki O, Takagi A \& Kojima T 2000 Ryudocan expression by luteinized granulosa cells is associated with the process of follicle atresia. Fertility and Sterility 74 1208-1214. (doi:10. 1016/S0015-0282(00)01587-9)

Sato A, Otsu E, Negishi H, Utsunomiya T \& Arima T 2007 Aberrant DNA methylation of imprinted loci in superovulated oocytes. Human Reproduction 22 26-35. (doi:10.1093/humrep/del316)

Sayasith K, Brown KA, Lussier JG, Dore M \& Sirois J 2006 Characterization of bovine early growth response factor- 1 and its gonadotropin-dependent regulation in ovarian follicles prior to ovulation. Journal of Molecular Endocrinology 37 239-250. (doi:10.1677/jme.1.02078)
Scanlon PF, Sreenan J \& Gordon I 1968 Hormonal induction of superovulation in cattle. Journal of Agricultural Science 70 179-182. (doi:10.1017/S0021859600011035)

Schams D, Kosmann M, Berisha B, Amselgruber WM \& Miyamoto A 2001 Stimulatory and synergistic effects of luteinising hormone and insulin like growth factor 1 on the secretion of vascular endothelial growth factor and progesterone of cultured bovine granulosa cells. Experimental and Clinical Endocrinology \& Diabetes 109 155-162. (doi:10.1055/s-200114839)

Schindler R, Nilsson E \& Skinner MK 2010 Induction of ovarian primordial follicle assembly by connective tissue growth factor CTGF. PLOS ONE $\mathbf{5}$ e12979. (doi:10.1371/journal.pone.0012979)

Shimizu T, Jayawardana BC, Tetsuka M \& Miyamoto A 2007 Differential effect of follicle-stimulating hormone and estradiol on expressions of vascular endothelial growth factor (VEGF) 120, VEGF164 and their receptors in bovine granulosa cells. Journal of Reproduction and Development 53 105-112. (doi:10.1262/jrd.18088)

Shozu M, Minami N, Yokoyama H, Inoue M, Kurihara H, Matsushima K \& Kuno K 2005 ADAMTS-1 is involved in normal follicular development, ovulatory process and organization of the medullary vascular network in the ovary. Journal of Molecular Endocrinology 35 343-355. (doi:10. 1677/jme.1.01735)

Singh J, Pierson RA \& Adams GP 1998 Ultrasound image attributes of bovine ovarian follicles and endocrine and functional correlates. Journal of Reproduction and Fertility 112 19-29. (doi:10.1530/jrf.0. 1120019)

Singh J, Dominguez M, Jaiswal R \& Adams GP 2004 A simple ultrasound test to predict the superstimulatory response in cattle. Theriogenology $\mathbf{6 2}$ 227-243. (doi:10.1016/j.theriogenology.2003.09.020)

Smith MJ \& Jennes L 2001 Neural signals that regulate GnRH neurones directly during the oestrous cycle. Reproduction 122 1-10. (doi:10.1530/ rep.0.1220001)

Smyth GK 2004 Linear models and empirical bayes methods for assessing differential expression in microarray experiments. Statistical Applications in Genetics and Molecular Biology 3 3. (doi:10.2202/1544-6115.1027)

Smyth GK 2005 Limma: Linear Models for microarray data. In Bioinformatics and Computational Biology Solutions using $R$ and Bioconductor, pp 397-420. Eds R Gentleman, V Carey, S Dudoit, R Irizarry \& W Huber. New York, NY, USA: Springer.

de la Sota RL, Simmen FA, Diaz T \& Thatcher WW 1996 Insulin-like growth factor system in bovine first-wave dominant and subordinate follicles. Biology of Reproduction 55 803-812. (doi:10.1095/biolreprod55.4.803)

Thomas FH, Wilson H, Silvestri A \& Fraser HM 2008 Thrombospondin-1 expression is increased during follicular atresia in the primate ovary. Endocrinology 149 185-192. (doi:10.1210/en.2007-0835)

Wandji SA, Gadsby JE, Barber JA \& Hammond JM 2000 Messenger ribonucleic acids for MAC25 and connective tissue growth factor (CTGF) are inversely regulated during folliculogenesis and early luteogenesis. Endocrinology 141 2648-2657. (doi:10.1210/en.141.7.2648)

Wildt DE, Woody HD \& Dukelow WR 1975 Induction of multiple ovulation in the cow with single injections of FSH and HCG. Journal of Reproduction and Fertility 44 583-586. (doi:10.1530/jrf.0.0440583)

Yancopoulos GD, Davis S, Gale NW, Rudge JS, Wiegand SJ \& Holash J 2000 Vascular-specific growth factors and blood vessel formation. Nature 407 242-248. (doi:10.1038/35025215)

Yasuda K, Hagiwara E, Takeuchi A, Mukai C, Matsui C, Sakai A \& Tamotsu S 2005 Changes in the distribution of tenascin and fibronectin in the mouse ovary during folliculogenesis, atresia, corpus luteum formation and luteolysis. Zoological Science 22 237-245. (doi:10.2108/zsj. 22.237)

Zalman Y, Klipper E, Farberov S, Mondal M, Wee G, Folger JK, Smith GW \& Meidan R 2012 Regulation of angiogenesis-related prostaglandin $F_{2 \alpha^{-}}$ induced genes in the bovine corpus luteum. Biology of Reproduction $\mathbf{8 6}$ 92. (doi:10.1095/biolreprod.111.095067)

Received 21 March 2013

First decision 10 April 2013

Revised manuscript received 16 May 2013

Accepted 3 June 2013 